\title{
UNIVERSITYOF
}

FORWARD

THINKING

WESTMINSTER用

WestminsterResearch

http://www.westminster.ac.uk/westminsterresearch

Impact of the Financial Crisis on the Performance of European

Acquisitions

Rao Nicholson, Rekha and Salaber, Julie

Rao Nicholson, Rekha and Salaber, Julie, Rao Nicholson, Rekha and Salaber, Julie (2014) Impact of the Financial Crisis on the Performance of European Acquisitions in: Temouri, Yama and Jones, Chris (ed.) International Business and Institutions after the Financial Crisis Palgrave Macmillan pp. 73-92 , 2014, Palgrave Macmillan,reproduced with permission of Palgrave Macmillan.

This extract is taken from the author's original manuscript and has not been edited. The definitive, published, version of record is available here:

http://www.palgrave.com/la/book/9781137367198

The WestminsterResearch online digital archive at the University of Westminster aims to make the research output of the University available to a wider audience. Copyright and Moral Rights remain with the authors and/or copyright owners.

Whilst further distribution of specific materials from within this archive is forbidden, you may freely distribute the URL of WestminsterResearch: ((http://westminsterresearch.wmin.ac.uk/)).

In case of abuse or copyright appearing without permission e-mail repository@westminster.ac.uk 


\section{IMPACT OF THE FINANCIAL CRISIS ON THE PERFORMANCE OF EUROPEAN ACQUISITIONS}

\section{Rekha Rao Nicholson}

Julie Salaber

This study looks at the impact of the recent financial crisis on the short-term performance of European acquisitions. We use institutional theory and transaction cost economic theory to study whether bidders derive lower or higher returns from acquisitions announced after 2008. We investigate shareholders' stock price reaction to 2245 deals which occurred during 2004-12 across 22 European Union countries. Our results from both univariate and multivariate analysis show that the deals announced in the post-crisis period, corresponding to the period of economic recession, generate higher returns to shareholders as compared to acquisitions announced in the pre-crisis period. We also test the relevance of the Economic and Monetary Union (EMU), that is, the Eurozone, to this value accrual during the recessionary period. We observe that non-EMU transactions obtain significantly higher gains vis-à-vis EMU transactions in the post-crisis years. Overall, announcement returns of European acquisitions have been affected by the financial crisis and the global recession; and companies that target countries with different currency regimes are likely to generate better returns from their acquisitions.

Keywords: Financial crisis, European Union, Acquisitions, Short-term performance,

\section{Eurozone}




\section{IMPACT OF THE FINANCIAL CRISIS ON THE PERFORMANCE OF EUROPEAN ACQUISITIONS}

Rekha Rao Nicholson

Julie Salaber

Shareholder wealth accretion is difficult to predict under most circumstances (Doukas and Kan, 2006, Cartwright and Schoenberg, 2006) and it can become a herculean task when cast under the shadows of a financial crisis (Mody and Negishi, 2000). In this chapter, we examine the under-explored effects of macroeconomic environment, that is the role of a supra-national institution like the Economic and Monetary Union (EMU), on the value creation ability of mergers and acquisitions (M\&As) for investors during the financial turmoil. We look at European acquisitions undertaken before and after the 2007-08 financial crisis to ascertain short-term shareholder returns. The majority of earlier studies either looked at domestic versus international aspects of $M \& A$ deals without paying attention to the regional and supra-national arrangements integrating different countries, or they have examined the performance of M\&A deals during 'normal' times which leaves out the effects of financial instability/economic recession within and across a political/economic union as a question yet to be answered.

In this study, we look at acquisitions across 22 European Union (EU) countries (both EMU and non-EMU) and expect countries within the EMU to experience similar institutional constraints from the economic slowdown (Rose and Spiegel, 2012).

As this chapter concentrates on the impact of the recent financial crisis on the short-term performance of European acquisitions, we hypothesize and test the following research questions: Did the financial crisis impact shareholder returns of European acquisitions? Does the EMU have an influence over the deals undertaken after the financial crisis? We use institutional theory and transaction cost economic theory to study whether bidders derive 
lower or higher returns from acquisitions announced after 2008. We investigate shareholders' stock price reaction to 2245 deals which occurred during 2004-12 across 22 EU countries.

By investigating the performance of European cross-border mergers and acquisitions before and after the financial crisis, our study fills a gap in the literature and links two interesting and equally important topics: cross-border M\&A activity and performance within an economic union (Cartwright and Schoenberg, 2006) and the impact of a crisis on business performance (Chau et al., 2012). Our study extends the argument on how a crisis will impact short-term returns on companies' inorganic growth strategy through mergers and acquisitions.

\section{BACKGROUND AND HYPOTHESES}

The European region has a Single European Market since 1992 (the European Union and its 28 member countries); and in 1999, the third stage of Economic and Monetary Union (EMU) was begun. The EMU gathers 17 countries with a common monetary policy supervised by the European Central Bank. The theoretical arguments which support links between trade liberalization, regional trade agreements and acquisitions have been discussed in Coeurdacier et al. (2009). In economic growth times, a monetary union will foster easy access to goods across national borders and help low-cost firms to buy high-cost firms effortlessly. Also, the integration of financial systems brought about by a monetary union will sustain the flow of equity capital between different countries. Such European integration should drive down the cost of conducting transactions within its borders. Also, due to the elimination of financial barriers within the Eurozone and the implementation of a single currency, home bias has greatly decreased within the euro area (Issing, 2006). The EMU has helped the manufacturing sector restructure its capital (Coeurdacier et al., 2009). It also reduces business stealing effect (Bjorvatn, 2004), thus, making it attractive for companies to 
engage in cross-border deals within the EMU. European economic integration reduces the reservation price of the target (Bjorvatn, 2004). Since the run up to 1992, the EMU element of foreign direct investment in Europe, including acquisitions, has grown considerably (Chesnais and Simonetti, 2000). European firms have used M\&As as a tool to build and develop intra-European networks (letto-Gillies et al., 2000). Over the last few decades, there has been a consolidation of stock exchanges which indeniably helped easing $M \& A$ transactions within the EU and beyond. For instance, OMX Group and Euronext Group are the merging of stock exchanges of various European countries.

Hence, looking at this natural setting where both domestic and cross-border deals within the EMU are likely to achieve equal returns to acquirers is an appealing area of research. Extant research on the short-term performance of bidders shows that, on average, acquirers earn negative abnormal returns (Kim et al., 2011, Klossek et al., 2012, Kobrin, 1979). The shortterm performance outcomes of cross-border acquisitions are mixed. US bidders acquiring in foreign locales can experience positive (Doukas and Travlos, 1988, Kostova et al., 2008) or negative (Ghemawat, 2001) returns. A study on UK cross-border bidders shows that they do not earn any significant abnormal return around the announcement date (Gregory and McCorriston, 2005).

The United States was in financial crisis from December 2007 (Reinhart and Rogoff, 2009) which was followed by the Eurozone debt crisis (Arezki et al., 2011). The global M\&A activity peaked in 2007 (UNCTAD, 2011); however, when the effects of the crisis were realized, the world's foreign direct investment amount, including acquisitions, fell from $\$ 1979$ billion to $\$ 1697$ billion in 2008 and the trend continued in 2009 (UNCTAD, 2009). Profit reduction and shrinking operational overheads have compelled businesses to focus their resources on their main business and not diverge into other industries or countries. Also, stock markets have lost much of their value (Te Velde et al., 2009), thus, limiting the value of transactions (UNCTAD, 2009). Yet, we observe many firms undertaking acquisitions. This is consistent with neoclassical theory suggesting that the occurrence of M\&As is a consequence of economic shocks (Harford, 2005, Mitchell and Mulherin, 1996). Hence, it is pertinent to 
scrutinize how these domestic and cross-border deals have fared after the global financial crisis.

The phenomenon of acquisitions and associated shareholder wealth accrual has been extensively researched (Cartwright and Schoenberg, 2006, Schoenberg, 2006). Studies have ranged from country (Eckert et al., 2010) and regional studies (Campa and Hernando, 2006) to those that address outcomes of these activities globally (Doukas and Kan, 2006). Comparative studies have looked at the returns of domestic versus cross-border acquisitions (Anand et al., 2005, Gubbi et al., 2010). In spite of all this, though studies have looked at acquisitions during other crises (Mody and Negishi, 2000, Williams and Nguyen, 2005), there is limited research on acquisitions during the recent financial crisis and the following economic recession. Similarly, there are limited studies on supranational institutions and their influence on regional M\&As.

We argue that our understanding of outcomes of acquisitions during a crisis can be enhanced by using multiple theoretical lenses to decipher the influence of the recent crisis on intra-European acquisitions.

\section{Differential value accrual in acquisitions before and after the financial crisis}

During the economic slowdown, resource redeployment for maximizing opportunity landscape for firm's survival is imperative. Acquisitions provide this opportunity to reconfigure product-mix (Krishnan et al., 2004). Similarly, resources are scarce during recessionary times, and acquisitions undergone after the financial crisis, akin to periods of evironmental jolts described by other authors, can be seen as a way to change firms' resources and capabilities (Wan and Yiu, 2009, Karim and Mitchell, 2000). These acquisitions would help companies to better adjust to the dynamic nature of business environment in the post-crisis period. To understand the value generated in acquisitions during the post-crisis period, it might be fruitful to look at the effect of the crisis on transaction costs between the acquiring and target firms. The use of transaction cost economics to explain costs involved in acquisitions derives its intellectual roots from the 
work of Williamson (1975). The argument developed from this theory centers around numerous imperfections that may be present in markets for intangible resources, including immobility, information asymmetries and related moral hazards, causal ambiguity, and monopoly. Williamson's seminal work also looks at the cost of conducting exchanges under various institutional circumstances that allow for protection of relationship-specific investments at the lowest total cost. Transaction cost economics also relates to secondary cost of negotiation and enforcement.

In the pre-crisis period, shareholder returns to European M\&As, both EMU and non-EMU, will be similar to returns widely discussed in extant literature. Also, in the pre-crisis period, the monetary union will lower the cost of transaction across borders and facilitate high-cost firms to be bought by low-cost firms (Coeurdacier et al., 2009). The financial integration within Europe will help in the reduction of the cost of capital, the removal of exchange rate risk, the creation of shared common trading platforms and the integration in post-trading market infrastructure (Coeurdacier et al., 2009).

In the post-crisis period, both EMU and non-EMU targets might face further devaluation in their immediate business environment (Pangarkar and Lie, 2004) and might experience erosion of firm value due to crisis-related economic distress (Wruck, 1990, Acharya and Schnabl, 2010, Mitton, 2002). During the financial crisis, companies are looking to quickly restructure and realign their assets (Campello et al., 2010) reducing the time spent on negotiations prior to acquisitions. Similarly, it can be argued that after the crisis, due to firm devaluation and stock market crash, overpayment for acquisitions is highly unlikely (Wan and Yiu, 2009), thus reducing the cost of individual transactions. Also, transaction costs are reduced by leveraging of internal capital markets by slack-rich firms who can acquire slackpoor firms with extraordinary growth opportunities (Goergen and Renneboog, 2004). Companies can generate synergies during turbulent economic times by adopting new resources and using new opportunities through acquisitions at low costs (Chattopadhyay et al., 2001, Meyer, 1982). We argue that in Europe the 2007-08 crisis will lend its affect on firm transactions and in deciding values gained by shareholders. Thus we expect that 
European companies benefit from the global recession when undertaking acquisitions activites, that is, shareholders give more value to acquisitions announced after the financial crisis due to higher risks and returns associated with undertaking acquisitions during bad economic times.

Hypothesis 1: European companies that announce acquisitions in the post-crisis period will achieve higher returns as compared to companies that announce acquisitions in the precrisis period.

\section{Returns to EMU vis-à-vis non-EMU transactions}

Institutional theorists like North (1990) have explored the role and effect of institutions on certainty in business transactions. Both formal and informal institutions introduce constraints that businesses need to understand and apply to engage in their day-to-day activities. Most of these institutions, formal and informal, are nation-specific and it is pertinent for companies to comprehend these rules of game to engage in economic activity across national borders. Similarly, countries that have similar institutions, including financial institutions, are likely to have companies with similar corporate structure and provide business environment that foster international acquisitions (Gubbi et al., 2010).

In the pre-crisis period, the EMU will help reducing the cost of capital, removing exchange rate risk, creating common trading platforms and integrating post-trading market infrastructure (Coeurdacier et al., 2009). The financial integration can also help restructuring several economic sectors such as the manufacturing sector (Coeurdacier et al., 2009). This will generate considerable traction for intra-EMU acquisitions. Thus, in terms of internationalization within Europe, non-Eurozone countries will encounter greater institutional dissimilarities. The environmental complexity is minimized when companies engage with host countries that have institutions comparable to their home country (Dikova et al., 2009). Acquirers are able to understand and adjust easily to business environments that are similar to their own (Kostova and Zaheer, 1999). Thus, in good economic times, being part of this exclusive club might prove to be an advantage for some companies internationalizing within 
Europe. Hence, in the pre-crisis period, transactions happening within the EMU are likely to derive higher returns than non-EMU transactions.

The economic recession spreading across Europe as a result of the 2007-08 financial crisis adds a fresh dynamics to the above story. The new financial and corporate assets made accessible through international acquisitions can be particularly useful following a systemic crisis that affects a large number of firms (Mody and Negishi, 2000). Too much similarity, as evidenced within EMU countries, might leave little space to harness cross-border differences and nuances that help businesses leverage their competitive advantages, especially in a recessionary economic landscape (Wan and Yiu, 2009, Gubbi et al., 2010). Indeed some European countries have different currencies and financial institutions as they are outside the EMU. Authors have indicated that differential tax systems can help cross-border deals (Goergen and Renneboog, 2004). Thus we argue that, within Europe, the distinction between EMU and non-EMU transactions is more relevant than the usual distinction between domestic and cross-border transactions. This non-EMU effect is likely to be amplified during bad economic times as firms are looking to find suitable partners to leverage their synergies (Mody and Negishi, 2000, Wan and Yiu, 2009). Thus, in this turbulent business climate, shareholder's returns are driven by what the market perceives as optimal coupling during acquisitions. In the years after 2008, the acquirer and target differences in terms of financial institutions and implied differences in institutional stability and access to finance can create a new mix of competencies and resources which can be suitable for adapting to new market conditions. Authors have looked at other high turbulent business environments, such as privatizations in transition economies, and argued that understanding country risk is essential to foreign acquisitions as it can fundamentally alter the basis upon which acquisition decisions are made (Uhlenbruck and De Castro, 2000). During the post-crisis period, we argue that financial contagion and associated economic, political and financial risk will have much larger impact on firm's strategic decision to acquire within the EMU or outside. We argue there are several dynamics within this region which could drive acquisitions and returns to transactions. For example, countries outside the EMU 
might be shielded from the immediate impact of emergent financial and economic turbulence from, say, the collapse of the common currency. Hence, for countries within the EMU, buying outside the Eurozone might signify risk diversification. Indeed, companies that choose to transact outside the EMU are creating a valuable service for investors by permitting them to diversify their portfolio risk indirectly by purchasing shares in multinationals outside the immediate impact region. Also, a non-EMU company buying an EMU firm could indicate risk diversification. Thus, we argue that stock markets will accordingly reward these non-EMU transactions as compared to intra-EMU deals.

Hypothesis 2: In the post-crisis period, European companies that engage in non-EMU deals derive better returns as compared to firms that engage in EMU deals.

\section{METHODOLOGY AND DATA}

\section{Event study methodology}

We use an event study methodology to assess the effect of the financial crisis and following recession on the short-term performance of European acquirers. This event study method measures and tests for the significance of abnormal stock returns around the acquisition's announcement date (MacKinlay, 1997). Abnormal returns are calculated as the difference between actual ex post and expected normal returns:

$$
A R_{i t}=R_{i t}-E\left(R_{i t} \mid X_{t}\right)
$$

where $A R_{i t,} R_{i t}$, and $E\left(R_{i t} \mid X_{t}\right)$ are the abnormal, actual and expected returns respectively at time $t$ and $X_{t}$ is the conditioning set of information in the normal return model. The abnormal return thus measures the stock market response to the announcement of an acquisition as visible in the movement of share prices of the acquiring firm. This method is similar to extant literature focusing on the short-term performance of mergers and acquisitions (Cartwright and Schoenberg, 2006, Moeller and Schlingemann, 2005, Gubbi et al., 2010, Doukas and Kan, 2006). Also, this ex ante performance measure prior to the actual integration of the 
target has been demonstrated to link well with ex post firm-level outcomes (Kale et al., 2002, Pangarkar and Lie, 2004).

We then calculate the cumulative abnormal return (CAR) for each deal by summing daily abnormal returns over the event window $[-5 ; 0]$ :

$C A R_{i}=\sum_{t=-5}^{0} A R_{i t}$

\section{Multivariate methodology}

In order to test our hypotheses, we run a cross-sectional analysis whereby we try to explain the cumulative abnormal return (CAR) with alternative independent variables.

For our first hypothesis, we construct a post-crisis dummy (POST-CRISIS) equal to one for all deals announced after the 2007-08 financial crisis; zero otherwise.

During the months from late 2007 to early 2009, all stock markets across Europe crashed as a result of the credit crunch initiated in the USA. Moreover, economic indicators reacted to the financial crisis with a lag and it was only during the first quarter of 2009 that all European countries were officially in an economic recession (Claessens et al., 2010). Thus we start our POST-CRISIS dummy in March 2009, which coincides with the end of stock market crashes across Europe.

In order to test our second hypothesis, we create a NON-EMU dummy, which equals one when the transaction happens across the EMU borders, that is, either the bidder or the target is located in a country outside the Eurozone. The idea is that these non-EMU acquisitions should provide greater diversification effects (along with potential foreign exchange risk) than acquisitions within the Eurozone, especially since the financial crisis and economic slowdown (Wan and Yiu, 2009). Thus we expect these non-EMU deals to earn significantly higher returns over the post-crisis period, and we test this hypothesis by calculating an interaction variable NON-EMUPOST-CRISIS.

In order to assess the true impact of the variables mentioned above, we need to control for deal-specific and firm-specific characteristics. Deal-specific variables commonly used in the 
M\&A literature (Capron and Shen, 2007, Denis et al., 2002, Dos Santos et al., 2008, Gubbi et al., 2010, Moeller and Schlingemann, 2005, Shleifer and Vishny, 2003, von Eije and Wiegerinck, 2010, Blackburn et al., 1997, Brown and Ryngaert, 1991, Faccio and Masulis, 2005, Martynova and Renneboog, 2008, Sudarsanam and Mahate, 2006) are: the status of the target, that is whether it is privately held (PRIVATE $=1$ ) or not; the industry relatedness, that is whether the bidder and the target belong to the same industry (SAMEIND=1); the mode of payment $(\mathrm{CASH}=1)$; the relative size of the target (RELATIVESIZE=deal value/market value of the acquirer); and the percentage of target company acquired during the transaction (PERCACQ). Firm-specific characteristics such as acquirer's size (MV) and price-to-book ratio (PTB) are also known to impact the short-term returns of the company (Lang et al., 1991, Moeller and Schlingemann, 2005, Rau and Vermaelen, 1998, Sudarsanam and Mahate, 2006).

\section{Data}

Data on European acquisitions come from Thomson One. We collected all deals fulfilling the following criteria: (i) the acquisition was completed between 2004 and 2012; (ii) the bidder owned a majority stake in the target company after the transaction; (iii) the country of both bidder and target companies is an EU member at the beginning of the sample and at least one counterparty is located in a Eurozone country; (iv) the acquirer is publicly traded; and (v) the value of the transaction is available. From this initial sample, we deleted few deals (deal value equals zero, announcement date and effective date are more than 3 years apart) and matched the data with the list of stocks from Thomson DataStream (each stock must be actively traded around the announcement date).

Our final sample consists of 2245 deals from 1088 bidders located in 20 different EU countries: Austria, Belgium, Cyprus, Denmark, Estonia, Finland, France, Germany, Greece, Republic of Ireland, Italy, Lithuania, Luxembourg, Netherlands, Poland, Portugal, Slovenia, Spain, Sweden, and United Kingdom. Table 1 shows the distribution of deals used in this study, by acquirer and target country. Note that Czech Republic and Hungary appear only as 
target countries as there are no bidders from these countries present in our sample. The top five acquirer's nations are France, the United Kingdom, Italy, Germany and Spain; and these countries are also the most targeted by European acquirers. The six countries which are shaded in grey are non-EMU countries, thus all shaded deals are considered as non-EMU transactions (acquisitions from non-EMU to non-EMU countries are not included in our sample).

[Table 1 about here]

The deal characteristics we collected from Thomson One are: the deal value, the acquirer/target SIC code, the target status, the method of payment, and the percentage acquired during the transaction. Daily financial data on stock return, market value, and priceto-book ratio of the acquirer are collected from Thomson DataStream. We also collected from DataStream daily market index returns and daily exchange rates of each EU currency with the USD. Table 2 presents the characteristics of stock markets in each country, that is, the number of stocks for which we collected daily returns, the stock market index used as a benchmark, and the currency of the returns. All returns and financial data were converted to USD.

[Table 2 about here]

Figure 1 presents various deal characteristics for the pre- and post-crisis periods across different categories of deals: domestic deals within the EMU, cross-border deals within the EMU and cross-border deals between EMU and non-EMU countries.

[Figure 1 about here]

Table 3 reports the correlation coefficients across all our variables. Overall, most variables are not significantly correlated, the highest coefficient being 25 per cent correlation between PRIVATE and PERCACQ.

[Table 3 about here] 


\section{RESULTS}

\section{Univariate analysis of CAR}

Table 4 presents the results of the univariate analysis for CAR[-5;0]. CARs are averaged over two sub-periods, pre- and post-crisis, and Student tests are performed in order to compare the difference of CAR between the two periods. Across all deals (left side of the table), abnormal returns earned in the post-crisis period are significantly higher than abnormal returns earned before 2009. Deals announced after the crisis earned on average an extra 0.69 per cent return (equivalent to 2.5 per cent a month). This is a preliminary indication of a significant difference in the performance of acquisitions announced before versus after the financial crisis, which we sought to test in the first hypothesis.

In the right side of the table, CARs are averaged across EMU and non-EMU transactions in order to further investigate these abnormal returns. We perform additional Student tests to compare abnormal returns between EMU and non-EMU deals. On one hand, the significant difference we found for all deals between the two periods is entirely due to significantly higher abnormal returns for non-EMU acquisitions in the second period. Indeed non-EMU transactions earn an extra 6 per cent monthly return when announced after the crisis; whereas there is no statistical difference between pre- and post-crisis EMU deals. On the other hand, testing for the statistical difference in CARs between EMU and non-EMU acquisitions reveals that non-EMU deals earn significantly higher returns $(+5.4$ per cent per month) than EMU deals, but only in the post-crisis period.

In the middle part of the table, we also provide a distinction of average CARs between domestic and cross-border deals in order to highlight a potential cross-border effect previously emphasized in the literature (Gubbi et al., 2010, Moeller and Schlingemann, 2005). Again we test for the statistical difference in CARs both between the pre- and postcrisis periods and between cross-border and domestic acquisitions. Student tests of these differences are not all statistically significant. When comparing domestic and cross-border deals, we do not find any statistical difference in their CARs, both before and after the crisis. 
Thus European acquisitions are not subject to the so-called cross-border effect. These results corroborate our hypothesis that, within the EU, the distinction between EMU and nonEMU transactions is more relevant than the usual distinction between domestic and crossborder acquisitions, especially in the post-crisis period.

[Table 4 about here]

\section{Cross-sectional analysis}

Table 5 shows the results of OLS regressions with White robust standard errors. In Table 5 model 1 , we include only the control variables in the regression. Throughout the multivariate analysis, three of the control variables significantly impact the short-term abnormal return of the acquirer. MV has a negative impact, which is consistent with the managerial hubris hypothesis (Roll, 1986, Moeller et al., 2004, Faccio et al., 2006) whereas PERCACQ and RELATIVESIZE have a positive effect on CAR. Moreover, cash-financed acquisitions are usually associated with higher returns (Faccio and Masulis, 2005, Martynova and Renneboog, 2008) as stock-financed transactions might signal to the investors that the stock is overvalued (Myers and Majluf, 1984). However our sample covers a long period of financial crisis and economic recession and thus is more concerned by undervalued than overvalued stocks.

Our first hypothesis finds strong support in Table 5 model 2. Our POST-CRISIS dummy records a positive and significant coefficient (5 per cent statistical significance). The coefficient is 0.0072 indicating returns of 2.6 per cent per month which shows evidence that acquisitions announced during the economic recession earned higher abnormal returns compared to transactions announced over 2004-08. This result is consistent with the univariate analysis, that is European acquirers on average generate greater returns for their shareholders when undertaking M\&A activities during the recessionary period, even after controlling for firm-specific and deal-specific characteristics.

[Table 5 about here] 
Table 5 model 3 presents the regression result with only the first dummy (NON-EMU). This variable alone doesn't have much impact on the short-term return of the acquirer. However the analysis over the post-crisis period shows a different picture. Indeed the interaction term NON-EMU*POST-CRISIS clearly emphasize a significantly higher return for non-EMU deals after the crisis. We present several models with inclusion of different explanatory variables. The extra monthly return relative to pre-crisis non-EMU deals is between $4.5-6.0$ per cent. It also means that during the economic recession in Europe, acquisitions across the Eurozone borders were better received by investors than intra-euro acquisitions. Overall, the crosssectional analysis is consistent with the univariate results in supporting our theoretical hypotheses. First, due to firm devaluation and low transaction costs as a consequence of the financial crisis, European acquirers benefited from the economic recession in their $M \& A$ activities and shareholders recognized these acquisitions as more value-generating, on average, than those announced before the crisis. Second, due to the existence of a monetary union in Europe, acquirers seeking to achieve higher returns through institutional and financial diversification need to target companies located in a country with a different currency regime.

\section{CONCLUSION}

This study investigates the impact of the recent financial crisis on the short-term performance of European acquisitions. First, we question whether the financial crisis has had any impact on the announcement returns of bidding companies. We find that the acquirer's short-term performance, measured by its abnormal stock return around the announcement date, is significantly higher in the post-crisis period than in the pre-crisis period. Second, we ask whether the membership of the Eurozone has been detrimental towards shareholder gains from European acquisitions during the recessionary period. Our results show that transactions involving non-EMU countries fare better than transactions 
within the EMU. One reason for this could be that, after the crisis, for EMU deals, the synergies existing between the target and acquirer are unlikely to materialize due to uncertainty in the EMU region. Also, countries in the EMU have experienced tremendous monetary contractions as compared to other European countries like the UK. Membership of the same monetary union brings with it certain rules, regulations and inflexibility, and countries outside this union are unlikely to carry this baggage; hence the market could potentially reward the inherent flexibility and financial certainty of the non-Eurozone currencies. Overall, we show that, within the EU, the distinction between EMU and non-EMU transactions is more relevant than the commonly used classification of domestic and crossborder deals, especially in the post-crisis period.

\section{Theoretical implications}

So far, most studies have focused on cross-border acquisitions (Campa and Hernando, 2006) without looking at how the membership of monetary, political and economic alliances might impact returns materialized for acquirers and targets. Though regionalism has its advantages, as our study shows, in the short-term and in the recessionary, post-crisis period, this could be a disabling factor for companies choosing to invest in countries that are part of regional alliances; thus limiting the returns they can accrue for their investment activities. Most of the theory is built on regional alliances in stable economic and financial times (Hernando et al., 2009) and/or does not consider the impact of a financial crisis (Charumilind et al., 2006). Our paper shows that there is a great need to extend the current theory in terms of regional scope as well as engage with the temporal aspect of financial instability. Finally, our study highlights the importance of supranational institutions in Europe like the EMU which can shape the possible outcomes for cross-border investment activities. We argue that institutional theory needs to take into account how these supranational institutions might adapt and limit the target's economic viability and acquirer's strategic activities and possible financial returns from investments in mergers and acquisitions due to the company's membership in certain monetary union. 


\section{Managerial implications}

Managers involved in acquisitions during the global economic recession are likely to derive higher returns from their investment than those acquisitions announced before the financial crisis. Though theory implies that acquirers can generate higher returns from acquisitions of low-priced high-value targets in foreign countries during recessionary times, our study presents a cautionary note. Managers need to take into account the regional monetary impact of the financial crisis which might prevent European companies from maximizing their returns from acquisitions. 
Table 1 Number of deals by acquirer and target country

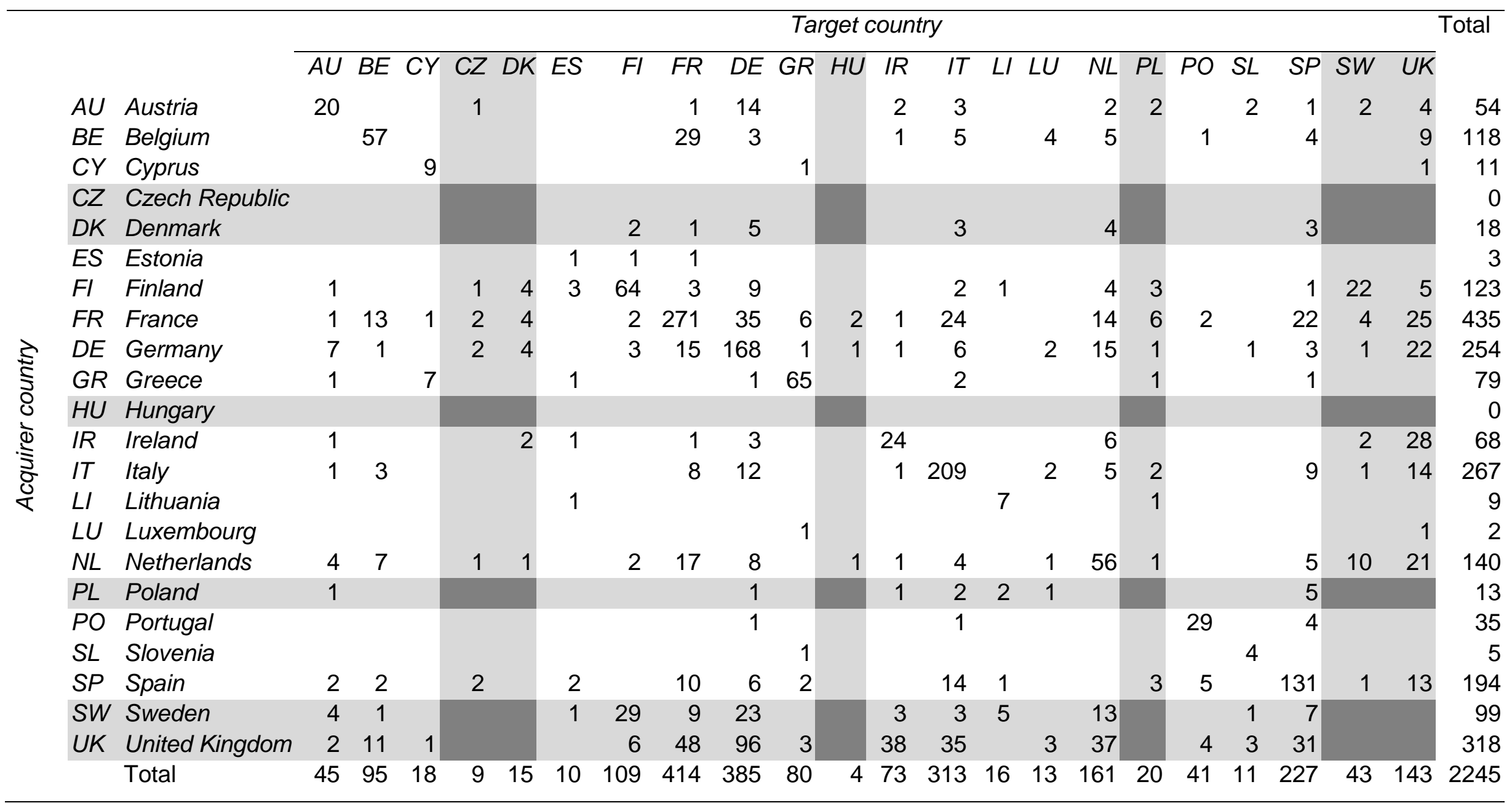


Table 2 Acquirer's country and stock market characteristics

$$
\text { EU year Number of }
$$

Bidder Nation of entry bidders Market index Currency

\begin{tabular}{|c|c|c|c|c|}
\hline Austria & 1995 & 25 & ATX & EUR \\
\hline Belgium & 1952 & 45 & BEL20 & EUR \\
\hline Cyprus & 2004 & 10 & FTSE Cyprus SE2O & EUR \\
\hline Denmark & 1973 & 11 & OMX Copenhagen 20 & DKK \\
\hline Estonia & 2004 & 3 & OMX Tallinn & EUR \\
\hline Finland & 1995 & 59 & OMX Helsinki 25 & EUR \\
\hline France & 1952 & 187 & CAC40 & EUR \\
\hline Germany & 1952 & 136 & DAX30 & EUR \\
\hline Greece & 1981 & 51 & ATHEX Composite & EUR \\
\hline Ireland Rep. & 1973 & 24 & ISEQ & EUR \\
\hline Italy & 1952 & 110 & FTSE MIB & EUR \\
\hline Lithuania & 2004 & 6 & OMX Vilnius & EUR \\
\hline Luxembourg & 1952 & 1 & Luxembourg SE General & EUR \\
\hline Netherlands & 1952 & 58 & AEX & EUR \\
\hline Poland & 2004 & 10 & TOTMKPO* & PLN \\
\hline Portugal & 1986 & 21 & PSI20 & EUR \\
\hline Slovenia & 2004 & 3 & TOTMKSJ* & EUR \\
\hline Spain & 1986 & 69 & IBEX35 & EUR \\
\hline Sweden & 1995 & 59 & OMX Stockholm 30 & SEK \\
\hline UK & 1973 & 200 & FTSE 100 & GBP \\
\hline
\end{tabular}




\begin{tabular}{|c|c|c|c|c|c|c|c|c|c|c|c|c|}
\hline & CAR[-5;0] & 1 & 2 & 3 & 4 & 5 & 6 & 7 & 8 & 9 & 10 & 11 \\
\hline MEAN & 0.011 & 0.293 & 0.504 & 0.304 & 387.1 & 0.830 & 0.273 & 0.825 & 2.692 & 0.685 & 0.395 & 0.324 \\
\hline STD & 0.059 & 0.455 & 0.500 & 0.460 & 2022.1 & 1.986 & 2.698 & 0.293 & 13.540 & 0.464 & 0.488 & 0.466 \\
\hline \multicolumn{13}{|c|}{ Correlation coefficients } \\
\hline 1 POST-CRISIS & $0.053 * *$ & 1.000 & & & & & & & & & & \\
\hline 2 CROSS-BORDER & -0.005 & -0.019 & 1.000 & & & & & & & & & \\
\hline 3 NON-EMU & $0.041 *$ & $-0.040 *$ & $0.656^{* * *}$ & 1.000 & & & & & & & & \\
\hline 4 DEALVALUE & $-0.037^{*}$ & -0.036 * & 0.006 & -0.013 & 1.000 & & & & & & & \\
\hline $5 \mathrm{MV}$ & $-0.074 * * *$ & * 0.000 & $0.059 * * *$ & -0.033 & $0.228^{* * *}$ & 1.000 & & & & & & \\
\hline 6 RELATIVESIZE & $0.063^{* * *}$ & -0.024 & -0.001 & 0.022 & 0.024 & -0.035 * & 1.000 & & & & & \\
\hline 7PERCACQ & $0.057^{* * *}$ & ${ }^{*}-0.011$ & $0.182^{* * *}$ & $0.213^{* * *}$ & -0.011 & $-0.162 * * *$ & 0.035 * & 1.000 & & & & \\
\hline 8 РTB & 0.005 & $-0.035^{*}$ & $0.044^{* *}$ & 0.025 & -0.006 & -0.007 & -0.002 & 0.001 & 1.000 & & & \\
\hline 9 SAMEIND & -0.013 & $-0.056 * * *$ & $0.052 * *$ & 0.046 ** & $0.069 * * *$ & $0.045^{* *}$ & 0.011 & -0.020 & 0.005 & 1.000 & & \\
\hline 10 PRIVATE & 0.000 & -0.021 & $0.069 * * *$ & $0.126 * * *$ & $-0.122 * * *$ & $-0.204 * * *$ & 0.003 & $0.253^{* * *}$ & -0.002 & -0.016 & 1.000 & \\
\hline $11 \mathrm{CASH}$ & -0.009 & $0.104^{* * *}$ & $0.134^{* \star *}$ & $0.180^{* * *}$ & 0.006 & 0.013 & 0.008 & -0.034 & 0.007 & -0.022 & -0.043 ** & 1.000 \\
\hline
\end{tabular}


Table $4 \quad$ Univariate analysis

\begin{tabular}{|c|c|c|c|c|c|c|c|c|}
\hline & All deals & Domestic & Cross-Border & Difference & EMU & non-EMU & Differenc & \\
\hline \multirow[t]{2}{*}{ Pre-crisis } & $0.91 \%$ & $0.98 \%$ & $0.84 \%$ & $-0.14 \%$ & $0.85 \%$ & $1.03 \%$ & $0.18 \%$ & \\
\hline & 1587 & 778 & 809 & & 1086 & 501 & & \\
\hline \multirow[t]{2}{*}{ Post-crisis } & $1.60 \%$ & $1.52 \%$ & $1.68 \%$ & $0.16 \%$ & $1.18 \%$ & $2.68 \%$ & $1.50 \%$ & $* *$ \\
\hline & 658 & 336 & 322 & & 477 & 181 & & \\
\hline \multirow[t]{2}{*}{ Difference } & $0.69 \%$ & $0.54 \%$ & $0.84 \%$ & & $0.33 \%$ & $1.65 \%$ & & \\
\hline & ** & & * & & & ** & & \\
\hline
\end{tabular}




\begin{tabular}{|c|c|c|c|c|c|c|c|}
\hline & (1) & (2) & (3) & (4) & (5) & (6) & (7) \\
\hline \multirow[t]{2}{*}{ POST-CRISIS } & & $0.00724^{* *}$ & & & 0.00350 & & 0.00392 \\
\hline & & $(0.00281)$ & & & $(0.00316)$ & & $(0.00332)$ \\
\hline \multirow[t]{2}{*}{ NON-EMU } & & & 0.00450 & & & 0.000147 & 0.00139 \\
\hline & & & $(0.00291)$ & & & $(0.00322)$ & $(0.00339)$ \\
\hline \multirow[t]{2}{*}{ NON-EMU*POST-CRISIS } & & & & $0.0165^{\star * *}$ & $0.0138^{* * *}$ & $0.0164^{\star \star *}$ & $0.0125^{\star *}$ \\
\hline & & & & $(0.00472)$ & $(0.00530)$ & $(0.00524)$ & $(0.00618)$ \\
\hline \multirow[t]{2}{*}{ CASH } & -0.00121 & -0.00188 & -0.00207 & -0.00255 & -0.00265 & -0.00256 & -0.00285 \\
\hline & $(0.00274)$ & $(0.00275)$ & $(0.00279)$ & $(0.00276)$ & $(0.00276)$ & $(0.00279)$ & $(0.00280)$ \\
\hline \multirow[t]{2}{*}{ MV } & $-0.00204^{* * *}$ & $-0.00204^{* * *}$ & $-0.00206^{* * *}$ & $-0.00202^{* * *}$ & $-0.00202^{* * *}$ & $-0.00202^{* * *}$ & $-0.00203^{* * *}$ \\
\hline & $(0.000657)$ & $(0.000656)$ & $(0.000657)$ & $(0.000655)$ & $(0.000655)$ & $(0.000656)$ & $(0.000656)$ \\
\hline \multirow[t]{2}{*}{ PERCACQ } & $0.0101^{* *}$ & $0.0101^{* *}$ & $0.00864^{*}$ & $0.00853^{\star}$ & $0.00878^{*}$ & $0.00850^{*}$ & $0.00846^{*}$ \\
\hline & $(0.00452)$ & $(0.00451)$ & $(0.00461)$ & $(0.00453)$ & $(0.00453)$ & $(0.00460)$ & $(0.00460)$ \\
\hline \multirow[t]{2}{*}{ PRIVATE } & -0.00347 & -0.00332 & -0.00378 & -0.00335 & -0.00330 & -0.00336 & -0.00339 \\
\hline & $(0.00275)$ & $(0.00274)$ & $(0.00275)$ & $(0.00274)$ & $(0.00274)$ & $(0.00275)$ & $(0.00275)$ \\
\hline \multirow[t]{2}{*}{ PTB } & 0.00181 & 0.00267 & 0.00145 & 0.00167 & 0.00211 & 0.00166 & 0.00206 \\
\hline & $(0.00922)$ & $(0.00922)$ & $(0.00922)$ & $(0.00920)$ & $(0.00921)$ & $(0.00920)$ & $(0.00921)$ \\
\hline \multirow[t]{2}{*}{ RELATIVESIZE } & $0.00127^{\star * *}$ & $0.00130^{* * *}$ & $0.00126^{* * *}$ & $0.00129^{* * *}$ & $0.00130^{* * *}$ & $0.00129^{* * *}$ & $0.00130^{\star * *}$ \\
\hline & $(0.000463)$ & $(0.000463)$ & $(0.000463)$ & $(0.000462)$ & $(0.000462)$ & $(0.000462)$ & $(0.000462)$ \\
\hline \multirow[t]{2}{*}{ SAMEIND } & -0.00139 & -0.000981 & -0.00161 & -0.00136 & -0.00116 & -0.00136 & -0.00121 \\
\hline & $(0.00275)$ & $(0.00275)$ & $(0.00275)$ & $(0.00274)$ & $(0.00275)$ & $(0.00275)$ & $(0.00275)$ \\
\hline \multirow[t]{2}{*}{ Constant } & 0.00683 & 0.00455 & 0.00722 & 0.00710 & 0.00595 & 0.00711 & 0.00592 \\
\hline & $(0.00453)$ & $(0.00461)$ & $(0.00454)$ & $(0.00452)$ & $(0.00464)$ & $(0.00453)$ & $(0.00464)$ \\
\hline
\end{tabular}




\begin{tabular}{|c|c|c|c|c|c|c|c|}
\hline Observations & 2,151 & 2,151 & 2,151 & 2,151 & 2,151 & 2,151 & 2,151 \\
\hline R-squared & 0.012 & 0.015 & 0.013 & 0.017 & 0.018 & 0.017 & 0.018 \\
\hline Adi. R-sa & 0.009 & 0.011 & 0.009 & 0.014 & 0.014 & 0.013 & 0.013 \\
\hline
\end{tabular}

Standard errors in parentheses, ${ }^{* * *} p<0.01,{ }^{* *} p<0.05,{ }^{*} p<0.1$, Dependent variable $=\mathrm{CAR}[-5 ; 0]$, White heteroskedasticity-consistent standard errors \& covariance 
Figure 1 Deal characteristics across two sub-periods (pre- and post-crisis) and for different categories of deals

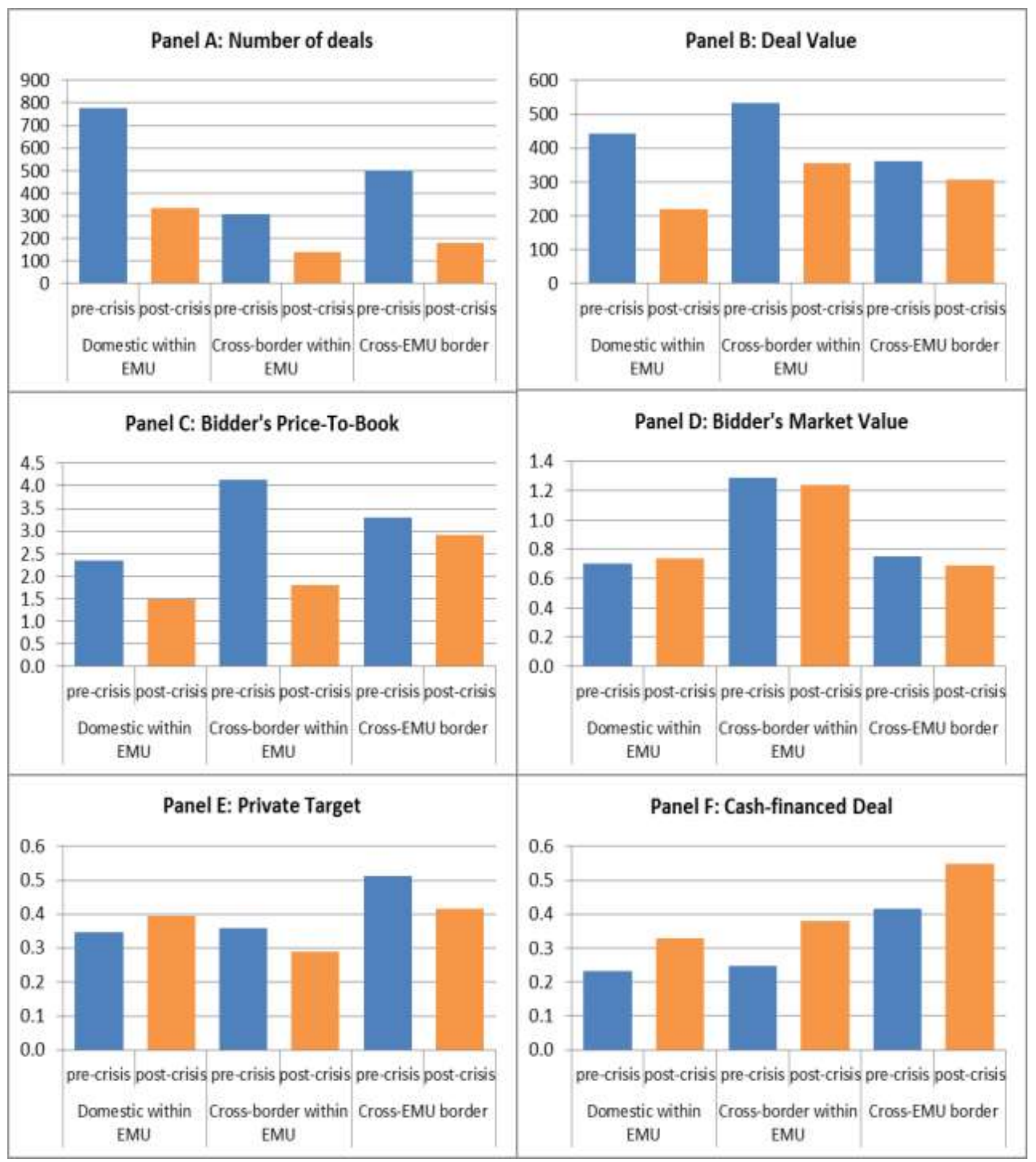




\section{REFERENCES}

Acharya, V. V. and Schnabl, P. (2010) 'Do Global Banks Spread Global Imbalances? AssetBacked Commercial Paper during the Financial Crisis of 2007-09'. IMF Economic Review, 58, $37-73$.

Anand, J., Capron, L. and Mitchell, W. (2005) 'Using acquisitions to access multinational diversity: thinking beyond the domestic versus cross-border M\&A comparison'. Industrial and Corporate Change, 14, 191-224.

Arezki, R., Candelon, B. and Sy, A. (2011) 'Sovereign rating news and financial markets spillovers: Evidence from the European debt crisis'. IMF Working Papers, 1-27.

Bjorvatn, K. (2004) 'Economic integration and the profitability of cross-border mergers and acquisitions'. European Economic Review, 48, 1211-1226.

Blackburn, V. L., Dark, F. H. and Hanson, R. C. (1997) 'Mergers, Method of Payment and Returns to Manager- and Owner-Controlled Firms'. Financial Review, 32, 569-589.

Brown, D. T. and Ryngaert, M. D. (1991) 'The mode of acquisition in takeovers: Taxes and asymmetric information'. Journal of Finance, 46, 653-669.

Campa, J. M. and Hernando, I. (2006) 'M\&As performance in the European financial industry'. Journal of Banking and Finance, 30, 3367-3392.

Campello, M., Graham, J. R. and Harvey, C. R. (2010) 'The real effects of financial constraints: Evidence from a financial crisis'. Journal of financial economics, 97, 470-487.

Capron, L. and Shen, J. C. (2007) 'Acquisitions of private vs. public firms: Private information, target selection, and acquirer returns'. Strategic Management Journal, 28, 891-911.

Cartwright, S. and Schoenberg, R. (2006) 'Thirty years of mergers and acquisitions research: Recent advances and future opportunities'. British Journal of Management, 17, S1-S5.

Charumilind, C., Kali, R. and Wiwattanakantang, Y. (2006) 'Connected Lending: Thailand before the Financial Crisis'. The Journal of Business, 79, 181-218. 
Chattopadhyay, P., Glick, W. H. and Huber, G. P. (2001) 'Organizational actions in response to threats and opportunities'. Academy of Management Journal, 44, 937-955.

Chau, V. S., Thomas, H., Clegg, S. and Leung, A. S. M. (2012) 'Managing Performance in Global Crisis'. British Journal of Management, 23, S1-S5.

Chesnais, F. and Simonetti, R. (2000) 'Globalization, foreign direct investment and innovation'. European Integration and Global Corporate Strategies, 17, 1.

Claessens, S., Dell'Ariccia, G., Igan, D. and Laeven, L. (2010) 'Cross-country experiences and policy implications from the global financial crisis'. Economic Policy, 25, 267-293.

Coeurdacier, N., De Santis, R. A. and Aviat, A. (2009) 'Cross-border mergers and acquisitions and European integration'. Economic Policy, 24, 55-106.

Denis, D., Denis, D. and Yost, K. (2002) 'Global diversification, industrial diversification, and firm value'. Journal of Finance, 57, 1951-1979.

Dikova, D., Sahib, P. R. and Van Witteloostuijn, A. (2009) 'Cross-border acquisition abandonment and completion: The effect of institutional differences and organizational learning in the international business service industry, 1981-2001'. Journal of International Business Studies, 41, 223-245.

Dos Santos, M. B., Errunza, V. R. and Miller, D. P. (2008) 'Does corporate international diversification destroy value? Evidence from cross-border mergers and acquisitions'. Journal of Banking and Finance, 32, 2716-2724.

Doukas, J. and Kan, O. B. (2006) 'Does global diversification destroy firm value?'. Journal of International Business Studies, 37, 352-371.

Doukas, J. and Travlos, N. G. (1988) 'The effect of corporate multinationalism on shareholders' wealth: Evidence from international acquisitions'. Journal of Finance, 43, 1161-1175. Eckert, S., Dittfeld, M., Muche, T. and Rässler, S. (2010) 'Does multinationality lead to value enhancement? An empirical examination of publicly listed corporations from Germany'. International Business Review, 19, 562-574.

Faccio, M. and Masulis, R. W. (2005) 'The choice of payment method in European mergers and acquisitions'. Journal of Finance, 60, 1345-1388. 
Faccio, M., McConnell, J. J. and Stolin, D. (2006) 'Returns to acquirers of listed and unlisted targets'. Journal of Financial and Quantitative Analysis, 41, 197.

Ghemawat, P. (2001) 'Distance still matters'. Harvard business review, 79, 137-147.

Goergen, M. and Renneboog, L. (2004) 'Shareholder Wealth Effects of European Domestic and Cross-border Takeover Bids'. European Financial Management, 10, 9-45.

Gregory, A. and McCorriston, S. (2005) 'Foreign acquisitions by UK limited companies: Shortand long-run performance'. Journal of Empirical Finance, 12, 99-125.

Gubbi, S., Aulakh, P., Ray, S., Sarkar, M. and Chittoor, R. (2010) 'Do international acquisitions by emerging-economy firms create shareholder value: The case of Indian firms'. Journal of International Business Studies, 41, 397-418.

Harford, J. (2005) 'What drives merger waves?'. Journal of Financial Economics, 77, 529-560. Hernando, I., Nieto, M. J. and Wall, L. D. (2009) 'Determinants of domestic and cross-border bank acquisitions in the European Union'. Journal of Banking \& Finance, 33, 1022-1032. letto-Gillies, G., Meschi, M. and Simonetti, R. (2000) 'Cross-border mergers and acquisitions'. European Integration and Global Corporate Strategies, 17, 51.

Issing, O. (2006) 'Globalization: Opportunities and challenges for the world, Europe and Austria'. European Central Bank.

Kale, P., Dyer, J. H. and Singh, H. (2002) 'Alliance capability, stock market response, and long term alliance success: the role of the alliance function'. Strategic Management Journal, 23, 747767.

Karim, S. and Mitchell, W. (2000) 'Path-dependent and path-breaking change: reconfiguring business resources following acquisitions in the US medical sector, 1978-1995'. Strategic management journal, 21, 1061-1081.

Kim, J. Y., Haleblian, J. and Finkelstein, S. (2011) 'When Firms Are Desperate to Grow via Acquisition: The Effect of Growth Patterns and Acquisition Experience on Acquisition Premiums'. Administrative science quarterly, 56, 26-60. 
Klossek, A., Linke, B. M. and Nippa, M. (2012) 'Chinese enterprises in Germany: Establishment modes and strategies to mitigate the liability of foreignness'. Journal of World Business, 47, 3544.

Kobrin, S. J. (1979) 'Political risk: A review and reconsideration'. Journal of International Business Studies, 10, 67-80.

Kostova, T., Roth, K. and Dacin, M. T. (2008) 'Note: Institutional Theory in the Study of Multinational Corporations: A Critique and new Directions'. Academy of Management Review, 33, 994-1006.

Kostova, T. and Zaheer, S. (1999) 'Organizational legitimacy under conditions of complexity: The case of the multinational enterprise'. Academy of Management Review, 24, 64-81. Krishnan, R. A., Joshi, S. and Krishnan, H. (2004) 'The influence of mergers on firms' productmix strategies'. Strategic Management Journal, 25, 587-611.

Lang, L. H. P., Stulz, R. M. and Walkling, R. A. (1991) 'A test of the free cash flow hypothesis: The case of bidder returns'. Journal of Financial Economics, 29, 315-335.

MacKinlay, A. (1997) 'Event studies in economics and finance'. Journal of Economic Literature, $35,13-39$.

Martynova, M. and Renneboog, L. (2008) 'A century of corporate takeovers: What have we learned and where do we stand?'. Journal of Banking and Finance, 32, 2148-2177.

Meyer, A. D. (1982) 'Adapting to environmental jolts'. Administrative science quarterly, 515-537. Mitchell, M. L. and Mulherin, J. H. (1996) 'The impact of industry shocks on takeover and restructuring activity'. Journal of Financial Economics, 41, 193-229.

Mitton, T. (2002) 'A cross-firm analysis of the impact of corporate governance on the East Asian financial crisis'. Journal of financial economics, 64, 215-241.

Mody, A. and Negishi, S. (2000) 'The role of cross-border mergers and acquisitions in Asian restructuring'. World Bank, July.

Moeller, S. B. and Schlingemann, F. P. (2005) 'Global diversification and bidder gains: A comparison between cross-border and domestic acquisitions'. Journal of Banking and Finance, $29,533-564$. 
Moeller, S. B., Schlingemann, F. P. and Stulz, R. M. (2004) 'Firm size and the gains from acquisitions'. Journal of financial economics, 73, 201-228.

Myers, S. C. and Majluf, N. S. (1984) 'Corporate financing and investment decisions when firms have information that investors do not have'. Journal of Financial Economics, 13, 187-221. North, D. C. (1990) Institutions, institutional change and economic performance (Cambridge, England: Cambridge university press).

Pangarkar, N. and Lie, J. R. (2004) 'The impact of market cycle on the performance of Singapore acquirers'. Strategic Management Journal, 25, 1209-1216.

Rau, P. R. and Vermaelen, T. (1998) 'Glamour, value and the post-acquisition performance of acquiring firms'. Journal of Financial Economics, 49, 223-253.

Reinhart, C. M. and Rogoff, K. S. (2009) 'The aftermath of financial crises'. American Economic Review: Papers and Proceedings, 99, 466-472.

Roll, R. (1986) 'The hubris hypothesis of corporate takeovers'. Journal of Business, 197-216. Rose, A. K. and Spiegel, M. M. (2012) 'Cross-country causes and consequences of the 2008 crisis: Early warning'. Japan and the World Economy, 24, 1-16.

Schoenberg, R. (2006) 'Measuring the Performance of Corporate Acquisitions: An Empirical Comparison of Alternative Metrics'. British Journal of Management, 17, 361-370.

Shleifer, A. and Vishny, R. W. (2003) 'Stock market driven acquisitions'. Journal of Financial Economics, 70, 295-311.

Sudarsanam, S. and Mahate, A. A. (2006) 'Are Friendly Acquisitions Too Bad for Shareholders and Managers? Long-Term Value Creation and Top Management Turnover in Hostile and Friendly Acquirers'. British Journal of Management, 17, S7-S30.

Te Velde, D. W., Ackah, C., Ajakaiye, O., Aryeetey, E., Bhattacharya, D., Calì, M., Fakiyesi, T., Fulbert, A. G., Jalilian, H. and Jemio, L. C. 2009. The global financial crisis and developing countries. Overseas Development Institute.

Uhlenbruck, K. and De Castro, J. O. (2000) 'Foreign aquisitions in central and eastern europe: outcomes of privatization in transitional economies'. Academy of Management Journal, 43, 381402. 
UNCTAD (2009) World Investment Report: Transnational Corporations, Agricultural Production and Development (New York \& Geneva: UNCTAD).

UNCTAD (2011) World Investment Report 2011: Non-Equity Modes of Production and Development (Geneva: UNCTAD).

von Eije, H. and Wiegerinck, H. (2010) 'Shareholders' reactions to announcements of acquisitions of private firms: Do target and bidder markets make a difference?'. International Business Review, 19, 360-377.

Wan, W. P. and Yiu, D. W. (2009) 'From crisis to opportunity: Environmental jolt, corporate acquisitions, and firm performance'. Strategic Management Journal, 30, 791-801.

Williams, J. and Nguyen, N. (2005) 'Financial liberalisation, crisis, and restructuring: A comparative study of bank performance and bank governance in South East Asia'. Journal of Banking \& Finance, 29, 2119-2154.

Williamson, O. E. (1975) Markets and hierarchies: antitrust analysis and implications (New York: The Free Press).

Wruck, K. H. (1990) 'Financial distress, reorganization, and organizational efficiency'. Journal of financial economics, 27, 419-444. 